\title{
Familial lambdoid synostosis
}

INSERM

\section{Source}

INSERM. (1999). Orphanet: an online rare disease and orphan drug data base. Familial lambdoid synostosis. ORPHA:3267

Familial lambdoid synostosis is a rare, genetic cranial malformation characterized by unilateral or bilateral synostosis of the lambdoid suture in multiple members of a single family. Unilateral cases typically present ipsilateral occipitomastoid bulge, compensatory contralateral parietal and frontal bossing, displacement of one ear, lateral deviation of jaw and compensatory deformation of cervical spine while bilateral cases usually manifest with flat and widened occiput, displacement of both ears and frequent occurrence of raised intracranial pressure. 